\title{
DESIGN FREE SURFACE TANK ON FAST MISSILE BOAT 60M
}

\author{
Sutrisno, Andi Mawanto, Wawan Kusdiana, Cahya Kusuma. \\ Indonesian Naval Technology College, STTAL Surabaya Indonesia
}

\begin{abstract}
Rolling motion is important role in the stability of the ship. Predicting the motion of a ship design must be done to see the design performance. The magnitude of the resulting motion response will affect the comfort and safety of personnel and materials in the ship. For this reason, simulation and analysis rolling and pitching prediction are carried out when the ship is operating, with and without the addition of a free surface tank (FST) as a stabilizer system with variations in the FST base height, water volume, boat velocity, heading direction and the waves. The prediction of ship motion in this research is ushing shipmo software and to assess operational feasibility, the general criteria standard issued by NATO STAGNAG 4154 (US. Navy) and US Coast Guard. From the simulation results it was found that increasing the height of the FST base from the base line decreases rolling motion. At a height of $4 \mathrm{~m}$ the maximum response magnitude below the allowable standard is 3,365 deg, while at a height of $3 \mathrm{~m}$ above the allowable standard that is 4,734 deg. The addition of FST and variations in placement of the FST base height from the base line did not significantly affect the pitching motion of the ship. Heading direction, waves and operational speed of the ship need to be considered to get the minimum rolling motion response when the ship is operating.
\end{abstract}

Keywords : Fast Missile Boat 60M, Free Surface Tank, Pitching, Rolling, Shipmo.

\section{INTRODUCTION.}

The Indonesian Navy needs to modernize its power independently, efforts must be made to reduce dependence on foreign countries, especially the need for warships. One of the efforts in realizing independence is the Navy in collaboration with PT.PAL to make a 60-meter Fast Missile Ship (KCR). This ship is designed to be able to carry out combat role in sea state 4 and navigate to sea state 6 , so that when operating it will certainly get an external force from waves, currents or wind that will cause the ship to experience surging, swaying, heaving, rolling, pitching and yawing .

The existence of these movements cause the ship to become unstable, one way to overcome the instability is to add a stabilizer system.Against the background there emerged an idea to design a free surface tank stabilizer system at KCR 60 meters to reduce rolling and pitching motion when the ship was operating at sea.

\section{DESIGN METHOD}

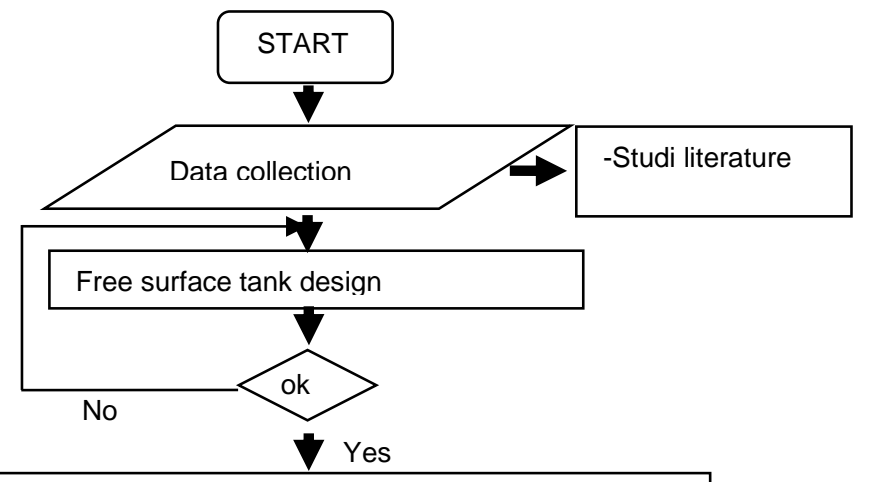

Analysis of dimensions, fluid volume and height of the FST on the rolling and pitching motion of the ship, and analyze the response of the rolling and pitching motion of the ship, when operating at sea states 4 and 6 .

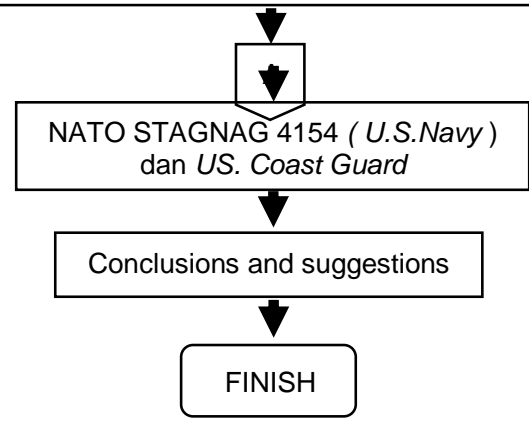

Figure 1 Research Flow 


\section{DISCUSSION AND ANALYSIS}

The following data are used in the analysis of this study:

Table 1 The Main Sizes of Ships

\begin{tabular}{|c|l|c|cc|}
\hline No & \multicolumn{1}{|c|}{ Parameter } & Simbol & \multicolumn{2}{|c|}{ Dimensi } \\
\hline 1. & Length & LPP & 53.66 & $\mathrm{~m}$ \\
2. & Breadth & $\mathrm{B}$ & 8.10 & $\mathrm{~m}$ \\
3. & Draft & $\mathrm{T}$ & 2.60 & $\mathrm{~m}$ \\
4. & Displacement & $\Delta$ & 407.16 & $\mathrm{Ton}$ \\
5. & Ship volume from sections & Vcalc & 445.88 & $\mathrm{~m}^{3}$ \\
6. & Block coefficient & $\mathrm{CB}$ & $0.39-$ & \\
7. & Midship section coefficient & $\mathrm{CM}$ & $0.7-$ & \\
8. & Long. centre of buoyancy & $\mathrm{XB}$ & 23.73 & $\mathrm{~m}$ \\
9. & Vert. centre of buoyancy & $\mathrm{KB}$ & 1.77 & $\mathrm{~m}$ \\
10. & Transverse BM & $\mathrm{BM}$ & 2.57 & $\mathrm{~m}$ \\
11. & Waterline area & $\mathrm{AW}$ & 314.37 & $\mathrm{~m}$ \\
12. & Long. metacentric height & $\mathrm{GMl}$ & $131.75 \mathrm{~m}$ \\
13. & Tot Transv. metacentric height & $\mathrm{GMt}$ & 0.99 & $\mathrm{~m}$ \\
14. & Transv. radius of inertia & $\mathrm{kxx}$ & 3.24 & $\mathrm{~m}$ \\
15. & Long. radius of inertia & $\mathrm{kyy}$ & 13.41 & $\mathrm{~m}$ \\
16. & Long. radius of inertia & $\mathrm{kzz}$ & 13.41 & $\mathrm{~m}$ \\
\hline
\end{tabular}

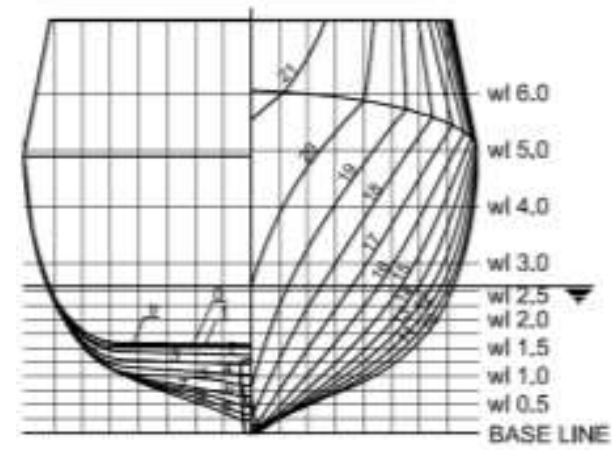

Figure 2. Body Plan

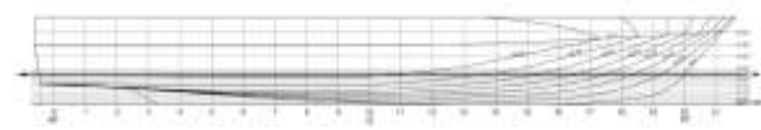

Figure 3. Lines Plan

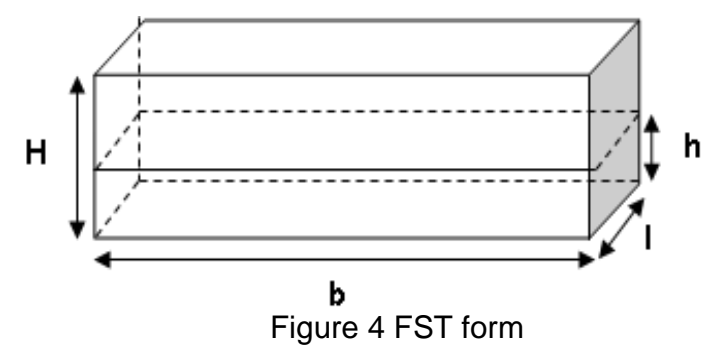

Tabel 2 Dimension of FST

\begin{tabular}{|c|c|c|c|c|}
\hline & $\begin{array}{c}\text { Length } \\
(1)\end{array}$ & $\begin{array}{c}\text { Breadth } \\
\text { ( b ) }\end{array}$ & $\begin{array}{c}\text { Height Tank } \\
\text { ( HT ) }\end{array}$ & Unit \\
\hline & 2.5 & 7.0 & 2.5 & $\mathrm{~m}$ \\
\hline
\end{tabular}

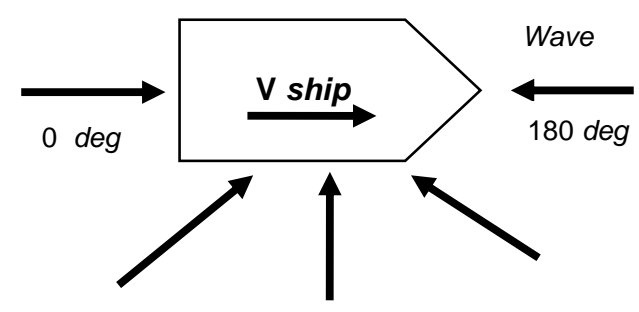

45 deg

$90 \mathrm{deg}$

$135 \mathrm{deg}$

Figure 5 Heading Direction

Tabel 3 FST condition

\begin{tabular}{|c|c|c|c|}
\hline No & & $\begin{array}{c}\text { The height of the } \\
\text { tank bottom from } \\
\text { the base line }=\mathrm{z} \\
(\mathrm{m})\end{array}$ & $\begin{array}{c}\text { FST } \\
\text { water } \\
\text { level }=\mathrm{h} \\
(\mathrm{m})\end{array}$ \\
\hline 1. & Without FST & - & - \\
\hline \multirow{2}{*}{2.} & \multirow{2}{*}{ FST } & \multirow{3}{*}{3} & 1 \\
\cline { 3 - 4 } & & & 1.5 \\
\cline { 3 - 4 } & & \multirow{2}{*}{4} & 2 \\
\cline { 3 - 4 } & & & 1.5 \\
\hline
\end{tabular}

\subsection{Analysis of Movement}

Movement analysis is carried out with the help of the SHIPMO software. In this simulation the ship is varied with speeds of 15 , 20 and 28 knots, the center of gravity of the ship is assumed to be the same as presented in Table 4 and the waves are used using the Pierson-Moskowitz spectrum formulation while the general criteria used in ship motion are issued by NATO STAGNAG 4154 (US Navy), and US. Coast Guard, see Table 5.

Table 5 Vessel Weight

\begin{tabular}{|c|l|l|}
\hline No & \multicolumn{1}{|c|}{ Koordinat } & \multicolumn{1}{|c|}{ Keterangan } \\
\hline 1. & $\mathrm{x}$-coord. of $\mathrm{COG}(\mathrm{XG})$ & 24.41 (wrt aft perpendicular) \\
2. & $\mathrm{y}$-coord. of $\mathrm{COG}(\mathrm{YG})$ & 0 \\
3. & $\mathrm{z}$-coord. of $\mathrm{COG}(\mathrm{ZG})$ & $3.36($ wrt keel $)$ \\
\hline
\end{tabular}


Table 6 General criteria

\begin{tabular}{|l|c|c|}
\hline & $\begin{array}{c}\text { NATO } \\
\text { STAGNAG } \\
4154 \\
\text { (US. Navy) }\end{array}$ & $\begin{array}{c}\text { US. Coast Guard } \\
\text { Cutter } \\
\text { certification } \text { plan }\end{array}$ \\
\hline Rolling amplitude (deg) & $4.0^{\circ} \mathrm{RMS}$ & $8^{\circ} \mathrm{SSA}$ \\
Pitching amplitude (deg) & $1.5^{\circ} \mathrm{RMS}$ & $3^{\circ} \mathrm{SSA}$ \\
\hline
\end{tabular}

*) $\mathrm{SSA}=2 \times \mathrm{RMS}$

\subsection{Rolling Motion Analysis}

Simulation results of the rolling motion with variations in speed and angle of the ship's heading, shown in Figure 6-8

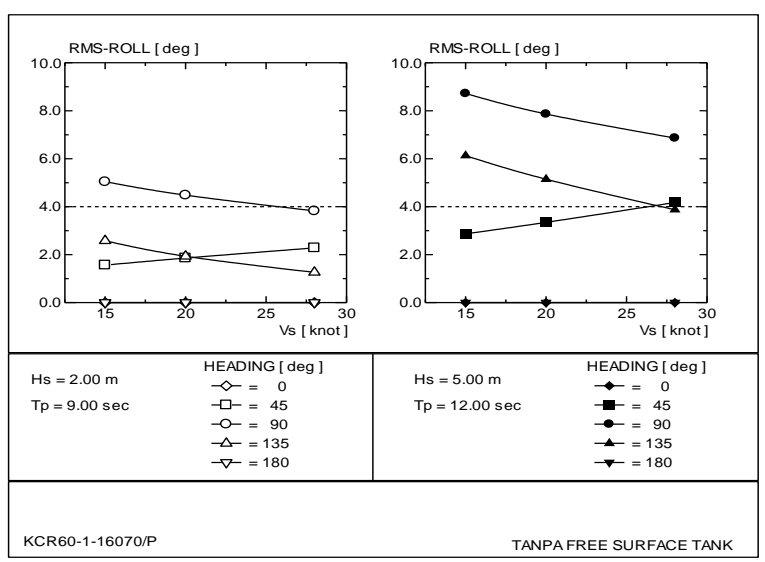

Figure 6 RMS $60 \mathrm{~K}$ Rolling Rolling Motion Without FST

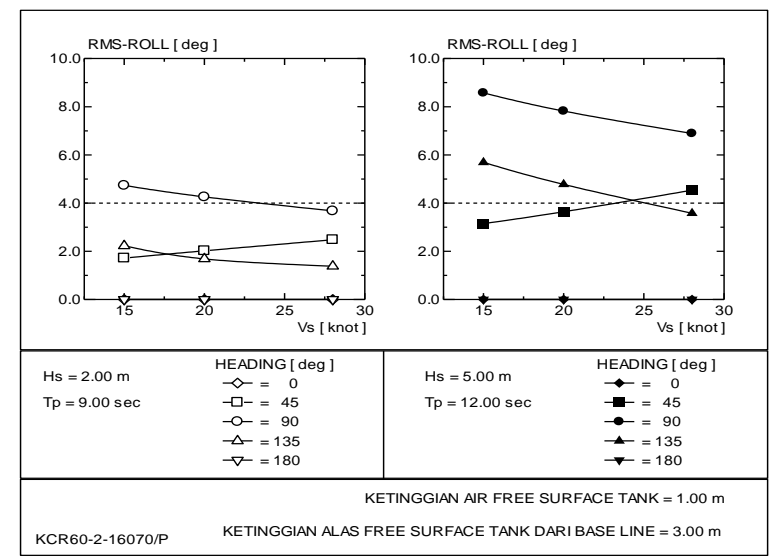

Figure 7.a RMS Motion Rolling KCR $60 \mathrm{~m}$, Altitude. FST $3 \mathrm{~m}$ from Base Line and Water Level $1 \mathrm{~m}$

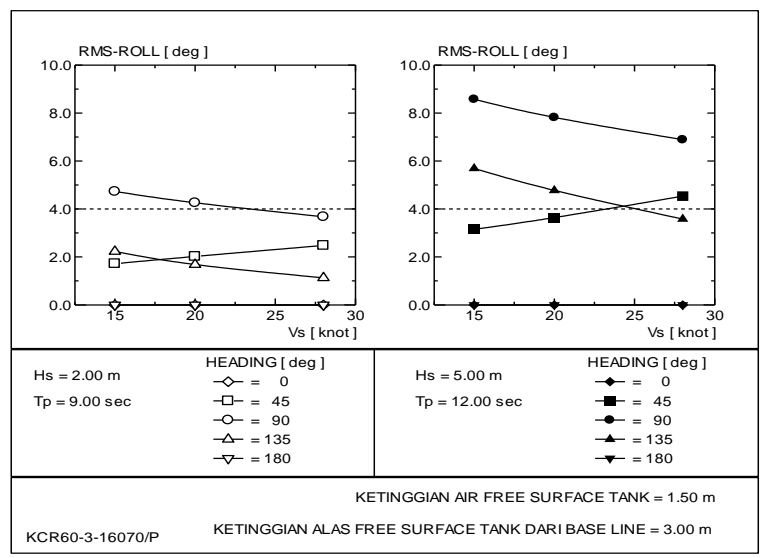

Figure 7.b RMS Motion Rolling KCR 60 m, Altitude. FST $3 \mathrm{~m}$ from Base Line and Water Level $1.5 \mathrm{~m}$

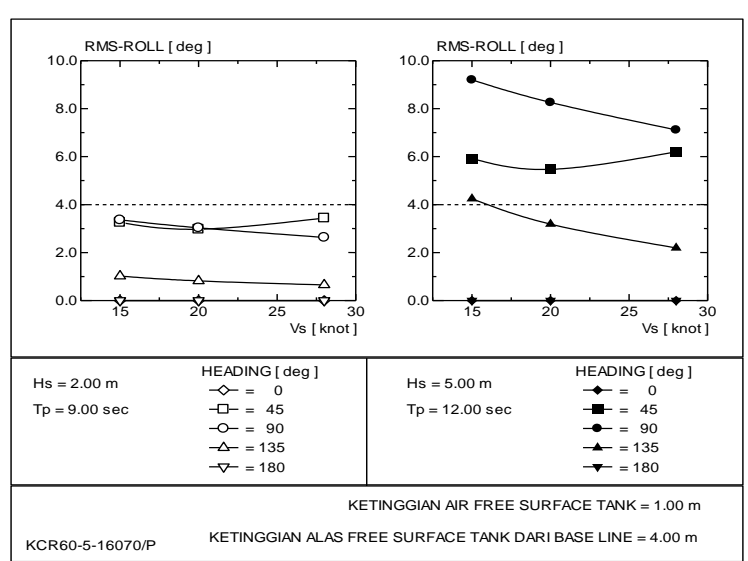

Figure 7.c RMS KCR Rolling Motion $60 \mathrm{~m}$, Altitude. FST $3 \mathrm{~m}$ from Base Line and Water Level $2 \mathrm{~m}$

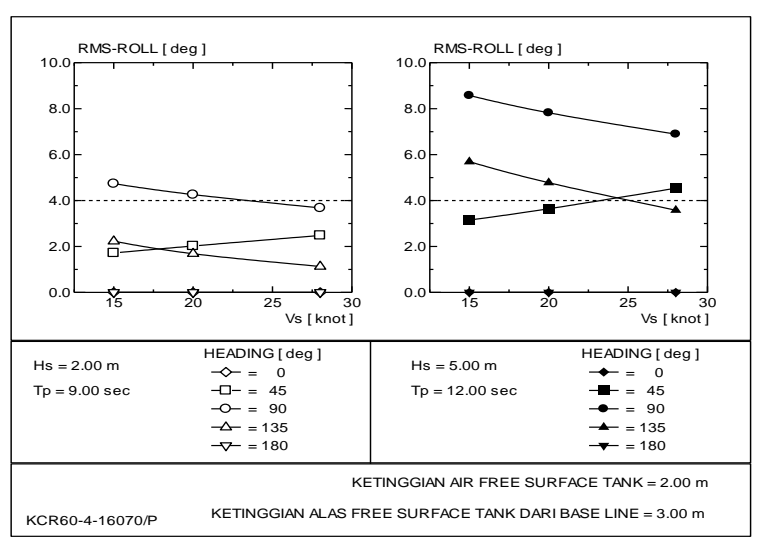

Figure 8.a RMS Motion Rolling KCR 60 m, Altitude. FST $4 \mathrm{~m}$ from Base Line and Water Level $1 \mathrm{~m}$ 


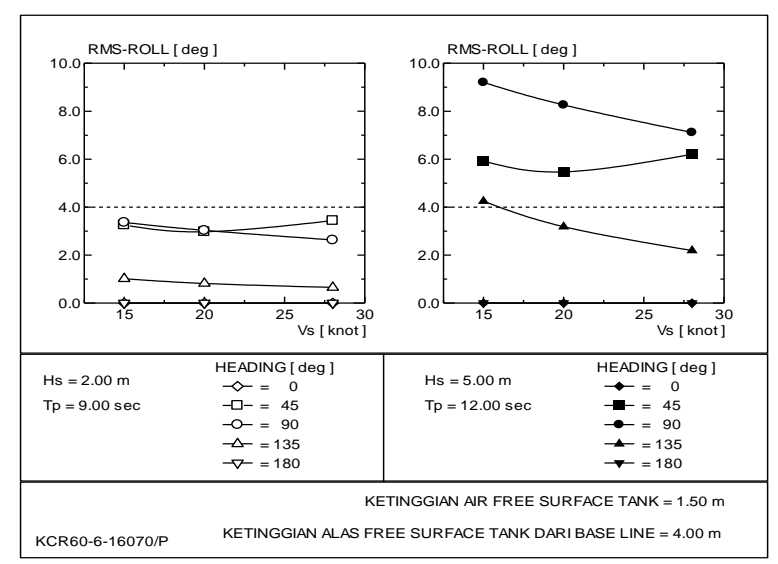

Figure 8.b RMS Motion Rolling KCR $60 \mathrm{~m}$, Altitude. FST $4 \mathrm{~m}$ from Base Line and Water Level $1.5 \mathrm{~m}$

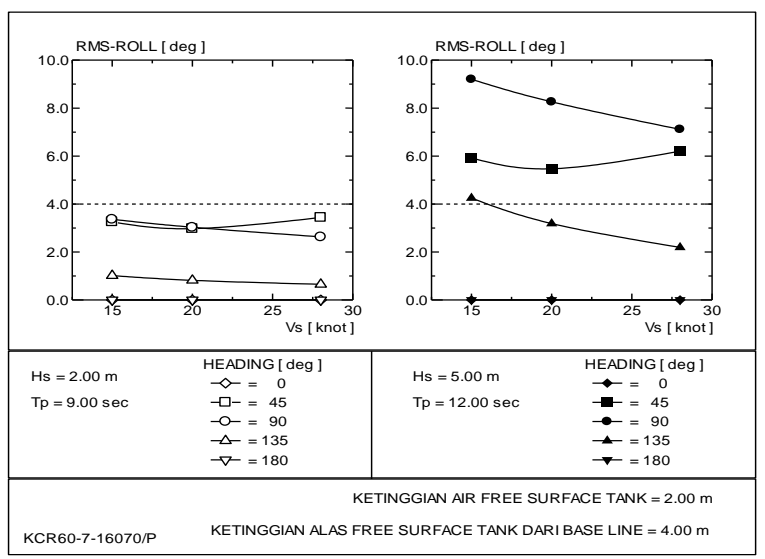

Figure 8.c RMS Motion Rolling KCR $60 \mathrm{~m}$, Altitude. FST $4 \mathrm{~m}$ from Base Line and Water Level $2 \mathrm{~m}$

From the results of the 60 -meter KCR simulation with and without the addition of FST, it is known that the effect of velocity with variations in wave height shows the same pattern or trend to changes in ship speed and heading. The biggest response of rolling motion occurs at low speed conditions with the direction of the heading from the side of the ship, while the smallest response occurs in the direction of the direction of the ship's direction, because the rolling motion is a motion that tends to transverse the ship, the direction of heading 90 deg is very dominant affecting the movement. The magnitude of the response of the motion increases with the increase in wave height and the increase in response to the rolling motion is almost twice that of the response at the wave height below

\subsubsection{Effect of FST base height on rolling}

The results of rolling motion prediction with variations in the laying height of the FST base 3 and 4 meters from the base line have the same pattern or trend to changes in speed and heading of the ship, the magnitude of the response decreases with increasing height of the FST base, the maximum magnitude of rolling motion response at the height of the FST base 4 meters from the base line are below the general seakeeping criteria of 3,365 RMS, see Figure 7-8.

\subsubsection{Effect of FST water level on rolling}

From the simulation results it is known that the water level in the FST has no effect on the resulting rolling damping, because the magnitude of the response and the resulting pattern or trend are the same, this can be seen in Figure 7-8.

\subsection{Pitching Motion Analysis}

Simulation results of pitching motion modes with variations in speed and angle of the ship's heading are shown in Figure 9-11.

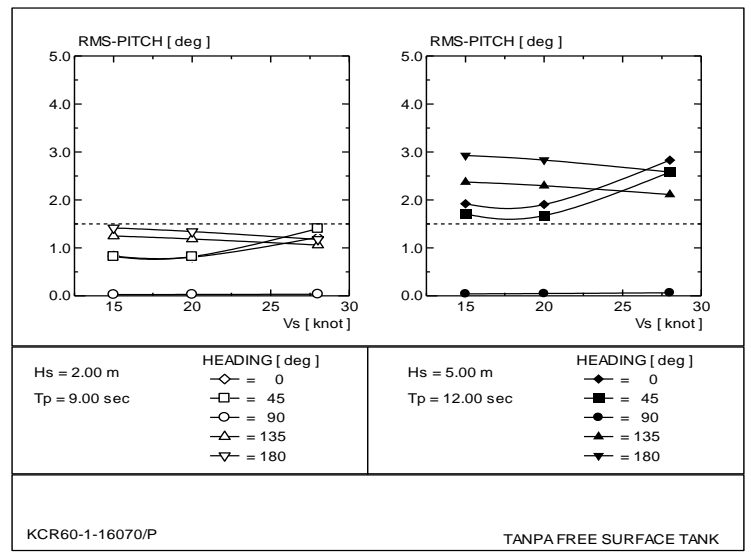

Figure 9 RMS Motion of KCR 60 m Pitching Without FST 


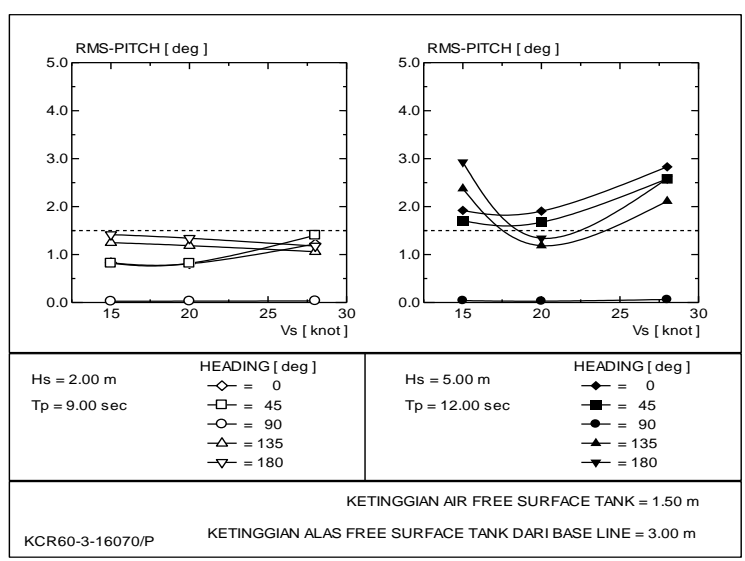

Figure 10.a RMS KCR Pitching Motion $60 \mathrm{~m}$, Height of FST Base $3 \mathrm{~m}$ from Base Line and Water Level $1 \mathrm{~m}$

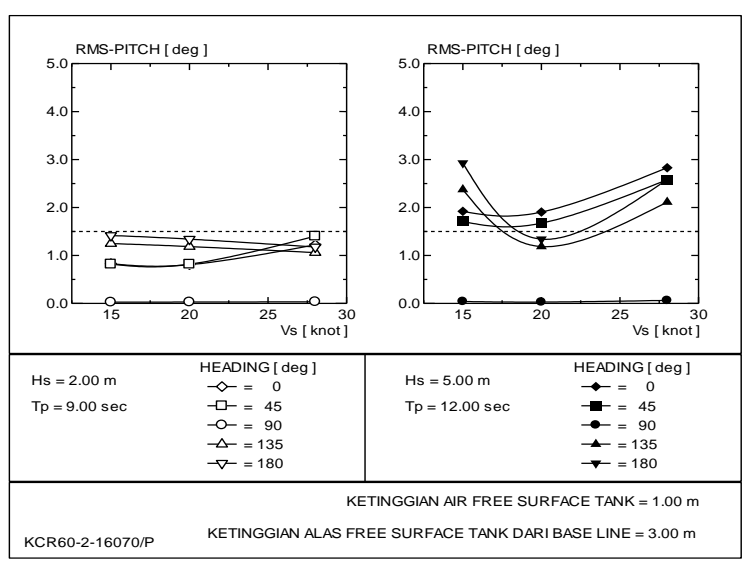

Figure 10.b RMS Motion of KCR Pitching 60 $\mathrm{m}$, Height of FST Pedestal $3 \mathrm{~m}$ from Base Line and Water level $1.5 \mathrm{~m}$

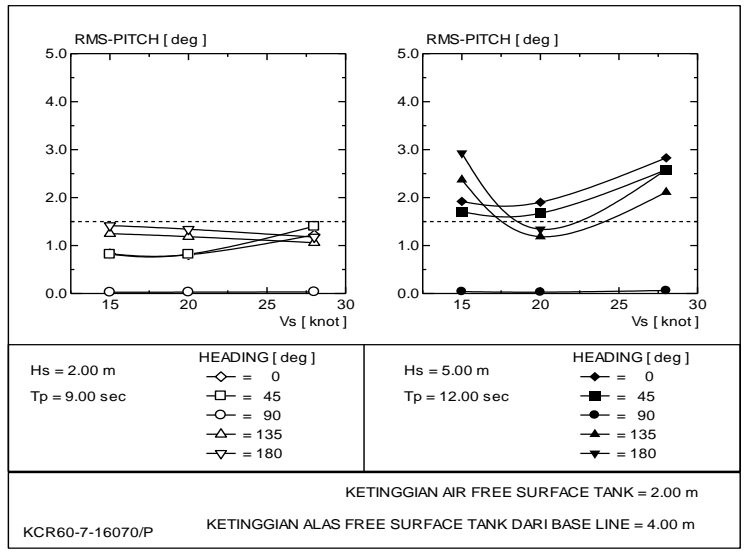

Figure 10.c RMS Motion of KCR Pitching 60 $\mathrm{m}$, Height of FST Base $3 \mathrm{~m}$ from Base Line and Water Level of $2 \mathrm{~m}$

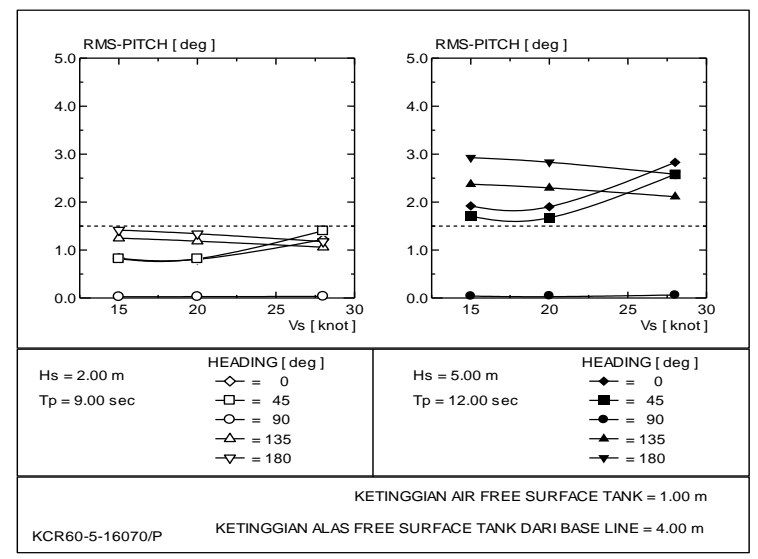

Figure 11.a RMS Motion of KCR Pitching 60 $\mathrm{m}$, Height of FST Base $4 \mathrm{~m}$ from Base Line and Water Level of $1 \mathrm{~m}$

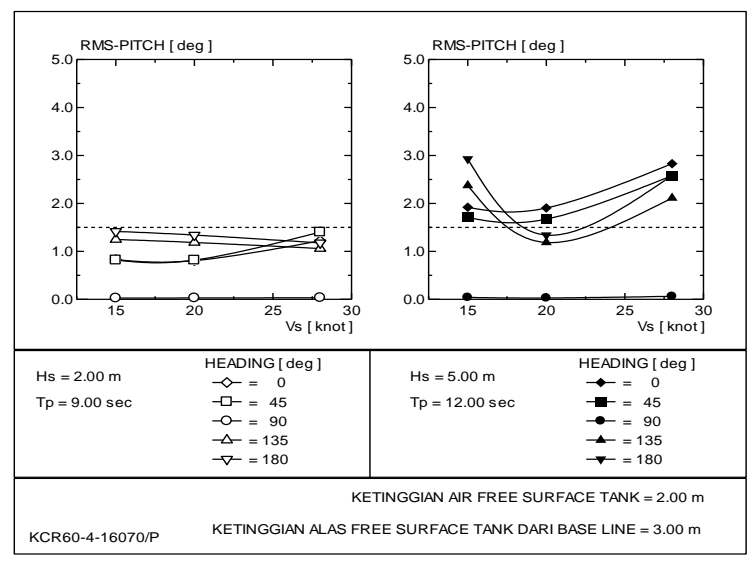

Figure 11.b RMS Kitch Pitching Motion $60 \mathrm{~m}$, Height of FST Base $4 \mathrm{~m}$ from Base Line and Water Height of $1.5 \mathrm{~m}$

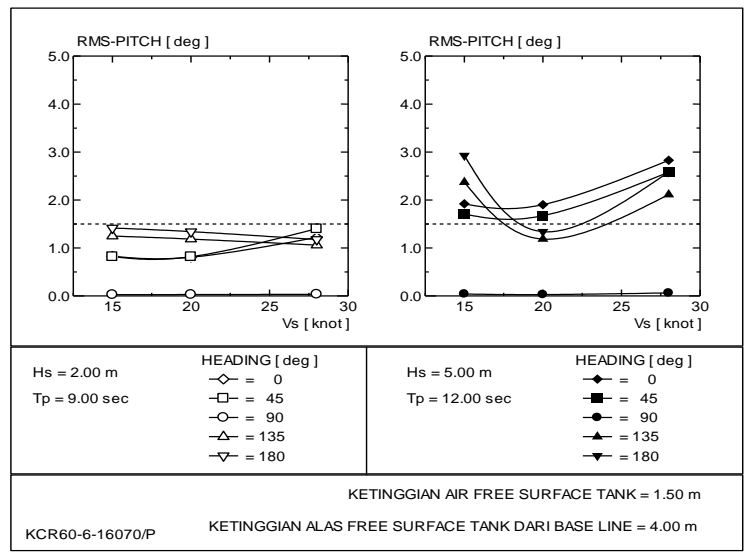

Figure 11.c RMS of KCR Pitching Motion 60 $\mathrm{m}$, Height of FST Pedestal $4 \mathrm{~m}$ from Base Line and Water Height of $2 \mathrm{~m}$ 
In the prediction of 60 meter KCR pitching motion with and without the addition of FST, it was found that the influence of the speed of the ship was less dominant in the RMS pitching produced, the effect of velocity with variations in wave height showed the same pattern or trend to changes in ship speed and heading. The greatest response of pitching motion occurs at low speed conditions with the direction of the direction of the ship's direction, while the smallest response occurs in the direction of the heading from the side of the ship, because pitching is a motion that tends to elongate the ship, heading direction $0,45,135$ and 180 deg is very dominant influence the movement. The magnitude of the motion response increases with increasing wave height, the increase in response in pitching motion is twice that of the response at the wave height below.

\subsubsection{Influence of FST base height with pitching}

The results of the pitching motion prediction with variations in the height of the base of the FST have no effect on the resulting pitching motion, because the magnitude of the response and the pattern or trend do not change, see Figure 10-11.

\subsubsection{Effect of FST water level on pitching}

From the simulation results it is known that the water level at the FST does not affect the pitching motion produced, because it has the same magnitude of response and pattern or trend, this can be seen in Figure 10-11.

From all simulations with variations and existing conditions, it is known that overall the 60 meter KCR design that is simulated can be used to operate at sea states 4 and 6 by paying attention to the heading direction, wave height and operational speed of the ship. And the need to add simple rolling and pitching dampers such as bilge keel and trim tabs to help dampen rolling and pitching.

\section{Conclusion}

From the results of the analysis of the FST design on the 60 meter KCR using shipmo software, it can be concluded:

a. Generally, the 60 meter KCR design which is simulated with and without the addition of FST can be used to operate in sea states 4 and 6 taking into account the direction of the heading and the operational speed of the ship.

b. The decrease in rolling occurs as the height of the FST base rises from the base line. Rolling maximum at $3 \mathrm{~m}$ height is 4,734 deg, while at $4 \mathrm{~m}$ height is 3,365 deg.

c. The addition of FST with variations in the placement of the FST base height from the base line does not affect the pitching motion of the ship.

d. The variation of water level in the FST has no effect on the magnitude of the resulting rolling and pitching motion response.

e. Rolling and pitching increase when there is an increase in waves..

f. Design and good placement of FST can reduce the rolling motion.

\section{ACKNOWLEDGEMENT}

The authors greatly acknowledge the support from STTAL Surabaya Indonesia for providing the necessary resources to carry out this research work. The authors are also grateful to the reviewers and journal editorial board for their many insightful comments, which have significantly improved this article.

\section{References}

Chang, WS., Main Characteristics, Cavitation Home Page at the University of texas, at Austin,

http://cavity.ce.utexas.edu/kinnas/wow/ public_html/waveroom/wow1/node2.ht ml, Sep 291999.

Chakrabarti, S. K., Hydrodynamic of Offshore Structure, London : SpringerVerlag.1987.

Djatmiko, E.B., Analisis Gelombang Acak, Materi kuliah Hidrodinamika II, Jurusan Teknik Kelautan ITS, Surabaya, 2002.

Djatmiko E.B and Murdijanto, Seakeeping: Perilaku Bangunan Apung diatas Gelombang, Jurusan Teknik Kelautan, 
Institut Teknologi Sepuluh Nopember, Surabaya, Indonesia, 2003.

Journee, J.M.J and Pinkster, J. Introduction in Ship Hydromechanics. Delft University of Technology. 2002.

J.W.J. Journee and W.W. Massie., Offshore Hydromecanics, first edition, Delft University of Technology. January 2001.

Perez, T., Ship Motion Control: Course Keeping and Rolling Stabilisation Using Rudder and Fins, Springer, Verlag Berlin, 2005.

St. Denis, M. and Pierson, W. J., On the Motion of Ships in Confused Seas, Transactions SNAME, 61:1-53, 1953. 